zgromadzonych uroczystą kolacją na zamku św. Jerzego pochodzącym z czasów arabsl-ej okupacji półwyspu.

Przy końcu spotkania wybrano członków stałego Biura, którymi są zwykle przedstawiciele głównych grup językowych i ustalono temat następnego spotkania: Nabożeństwa ludowe.

Tyniec

O. FRANCISZEK MAŁACZYŃSKI OSB

O. Franciszek Malaczyński OSB

\title{
25 ROCZNICA POWSTANIA PAPIESKIEGO INSTYTUTU LITURGICZNEGO W RZYMIE
}

Papieska Akademia Teologiczna św. Anzelma w Rzymie, wierna tradycjom Zakonu św. Benedykta, zawsze uwzględniała liturgię $w$ badaniach i w nauczaniu teologii.

W roku 1956 rozpoczęto pod kierunkiem O. Kuniberta Mo h l berga OSB wydawanie krytycznych opracowań tekstów starożytnych sakramentarzy w serii wydawniczej Rerum Ecclesiasticarum Documenta. Rozwijający się ruch liturgiczny zwrócił uwagę profesorów Wydziału Teologicznego na konieczność zorganizowania instytutu, który by zajął się naukowym wykładem liturgii i przygotował kwalifikowanych wykonawców spodziewanej reformy. Ojcowie: Cyprian Vagaggini, Salwator Marsili oraz Adrian Nocent $z$ entuzjazmem przystąpili do organizowania Instytutu Liturgicznego, ciesząc się poparciem ówczesnego opata prymasa Zakonu Bennona Guta oraz rektora Akademii Augustyna Mayera. Papież Jan XXIII zdając sobie sprawę $z$ potrzeb Kościoła, dnia 17 czerwca 1961 roku erygował „Papieski Instytut Liturgiczny" w łonie Wydziału Teologicznego Papieskiej Akademii św. Anzelma. W październiku 1961 roku Instytut rozpoczął pierwszy rok akademicki. Oprócz benedyktynów wykładali $w$ nim wybitni znawcy różnych działów liturgii $\mathrm{z}$ innych papieskich uczelni. Studenci rekrutowali się $\mathrm{z}$ całego świata. Dzięki wybitnym wykładowcom i dużemu zainteresowaniu odnową liturgii w calym Kościele, od początku Instytut zajął godne miejsce wśród innych specjalistycznych studiów w Rzymie. Pomyślny rozwój sprawił, że 23 sierpnia 1978 roku Papieski Instytut Liturgiczny zachowując swoją nazwę otrzymał prawa Wydziału $\mathrm{i}$ od tego roku nadaje stopnie licencjata i doktora Liturgii. Instytut wydaje wybitniejsze rozprawy swoich pracowników w serii Analecta Liturgica, a od trzech lat wychodzi perioryk Ecclesia Orans. Od roku 1982 Papieski Instytut Liturgiczny organizuje Międzynarodowe Kongresy Liturgiczne poświęcone wybranym zagadnieniom liturgicznym.

Papieski Instytut Liturgiczny współpracuje $\mathrm{z}$,Duszpasterskim Ośrodkiem Kultu i Uświęcenia" wikariatu miasta Rzymu, prowadząc kursy dla parafialnych animatorów liturgii. Instytut współpracuje również z Instytutem Liturgii Pastoralnej w Padwie oraz $z$ podobnymi instytucjami w Detroit i w Chicago. W ciągu 25 lat działalności Instytut wykształcił 1500 specjalistów, którzy obecnie wykładają liturgię w uniwersytetach i seminariach duchownych na całym świecie, redagują czasopisma liturgiczne, pracują w krajowych i diecezjalnych Komisjach liturgicznych. W Polsce większość wykładowców liturgii, to absolwenci Papieskiego Instytutu Liturgicznego w Rzymie. Dziewięciu absolwentów Instytutu pracuje w Komisji Episkopatu Polski do spraw Liturgii. Podobnie wielu 
pracowników Kongregacji Kultu Bożego ukończyło studia w Papieskim Instytucie Liturgicznym.

Dnia 1 czerwca 1986 Instytut obchodził 25 rocznicę założenia. Z tej okazji około godziny osiemnastej przybył do Opactwa św. Anzelma na Awentynie Ojciec święty Jan Paweł II. Witali go: Kard. Augustyn Mayer OSB, którego kościołem tytularnym jest kościół św. Anzelma, opat prymas Wiktor Dammertz OSB, rektor Papieskiej Akademii św. Anzelma Ansgar Chupungco OSB oraz przeor O. Mark Sheridan OSB. Ojciec święty udał się do zakrystii, gdzie ubrał szaty pontyfikalne i poprzedzany przez cały konwent św. Anzelma udał się procesjonalnie do kościoła, który wypełniali zaproszeni goście. Ojciec święty odprawił Nieszpory na uroczystość Najśw. Ciała i Krwi Chrystusa, którą w tę niedzielę obchodzono we Włoszech. Uroczyste Nieszpory poświęcone tajemnicy Eucharystii dobrze wyrażały dziękczynienie Instytutu, który od 25 lat zgłębia liturgię Kościoła. Po Nieszporach, w kościele odbył się uroczysty akt akademicki. Opat prymas przywitał Ojca świętego i przedstawił życie kolegium św. Anzelma. Podkreślił, że kolegium, które wkrótce będzie obchodziło 100-lecie istnienia, od początku wiernie sprawowało w chórze służbę Bożą i nadal ją sprawuje. Dzięki temu studium odbywa się w atmosferze modlitwy, a wykładowcy i studenci bez przerwy realizują swoje monastyczne powołanie i stanowią cząstkę modlącego się Kościoła. W modlitwie i w pracy jednoczą się przedstawiciele 61 klasztorów i 24 krajów z wszystkich kont-nentów. Rektor Akademi przedstawił jej życie naukowe, a jeden ze studentów br. Ferdynand Campana OFM w imieniu kolegów wyraził radość z możliwości studiowania w stolicy chrześcijaństwa.

Następnie Ojciec święty przemówił do wykładowców i studentów :tawiając im za wzór patrona Akademii św. Anzelma, arcybiskupa Canterbury i doktora Kościoła.

Po przemówieniu papieża złożono mu w darze wydawnictwa Instytutu. Rodzinny charakter tego obchodu podkreśliły dwa gesty papieża. Ojciec święty osobiście pozdrowił wszystkich wykładowców i studentów, a następnie udał się do reflektarza kolegium i spożył z nimi wieczerzę. Ten udział Ojca świętego w życiu wspólnoty był potwierdzeniem wartości życia monastycznego, które w bratniej miłości prowadzą przedstawiciele różnych narodów, języków i kultur.

Tyniec

O. FRANCISZEK MAEACZYÑSKI OSB

\title{
PRZEMÓWIENIE OJCA ŚWIĘTEGO JANA PAWLA II W KOŚCIELE ŚW. ANZELMA W RZYMIE W 25 ROCZNICEZ ZALOŻENIA PAPIESKIEGO INSTYTUTU LITURGICZNEGO
}

\author{
Czcigodny Opacie Prymasie, \\ Czcigodny Ojcze Rektorze, \\ Szanowni Profesorowie, \\ Drodzy Studenci,
}

1. Chętnie przybyłem na wzgórze Awentynu, które w Rzymie jest siedzibą głównego ośrodka monastycznego benedyktyńskiego, na spotkanie z wami, Wykładowcy i Studenci Akademii noszącej imię świętego Anzelma, mnicha i doktora Kościoła. Chcę się spotkać z wami, Mnisi benedyktyńscy, którzy 